\title{
MRS Sees Growth in University Chapters, Sections
}

The 1992 Fall Meeting Council approved petitions for two new university chapters and one new section, increasing the number of university chapters to 24 , the number of sections to eight.

If you are interested in joining one of these active organizations, call the president of the chapter or section closest to you-names and telephone numbers are listed below:

\section{MRS Sections}

Alabama, Daryush Ila, 205-851-5866

*East Tennessee, Dora F. Pedraza, 615-574-5083

Greater Pittsburgh, Sury G. Sankar, 412-268-5649

New Mexico, Charles Fleddermann, 505-277-5628

North Carolina, Carl C. Koch, 919-515-7340

North Texas, Russell F. Pinizzotto, 817-565-3310

Washington/Baltimore, Hamid Hojaji, 202-319-6705

Western New York, Gilbert A. Hawkins, 716-722-2349

\section{MRS University Chapters}

Alabama A\&M, Leslie Evelyn, 205-851-5866

Alfred University, Charles T. Hach, 607-871-2475

Carnegie Mellon University, Bob McFadden and Vijay Balakrishna, 412-268-8797

Cornell University, Paul Braun, 607-255-6684

Johns Hopkins University, Marietta Scanlon, 410-516-6077

Massachusetts Institute of Technology Monica L. Kaforey, 617-253-6999

Northwestern University, Andrew Yee, 708-491-7443

Pennsylvania State University, Girish Kelkar, 814-865-0889

Rensselaer Polytechnic Institute, Adam Selsley and Joshua Hugg, 518-276-4865 or 518-276-4632
*State University of New YorkBinghamton, Kathleen L. Covert, 607-777-4623

Stevens Institute of Technology, Gene Kulesha and Ed Furey, 201-216-5332

Texas A\&M University, Gregory F. Spencer, 409-845-5271

University of Alabama, James Cates, 205-348-5050

University of Arizona, John Lombardi, 602-322-2960

University of California-Berkeley, Tai D. Nguyen, 510-486-4051

University of California-Los Angeles, Tanya Faltens, 310-206-1255

University of Florida, Timothy M. Cheek 904-392-9821
University of Maryland, Edgar R. Seydel 301-405-7380

University of Michigan, Adam Schubring, 313-763-9797

University of Minnesota, $\mathrm{XiChu}$ 612-625-6083

University of Pittsburgh, Tim Klemmer 412-624-9894

University of Rochester, Deep Gupta, 716-275-0033

*University of Western Ontario, Jack Wallace, 519-679-2111

University of Wisconsin-Madison, Victor Wang, 608-263-2613

*Petitions accepted by Council at the 1992 Fall Meeting.

\section{UPCOMING CONFERENCES}

\section{Symposium on Microwaves to Be Featured at ACerS Annual Meeting}

The 95th Annual Meeting of the American Ceramic Society, to be held April 18-22 in Cincinnati, Ohio, will feature the symposium, Microwaves: Theory and Application in Materials Processing II. This symposium will focus on the increasingly important role of microwave energy in the fabrication of new and exciting materials. It will provide a forum for the exchange of information that can result in a better understanding of microwave/material interactions, leading to improved processing and new applications.

Endorsed by the Materials Research Society and the International Microwave Power Institute, the microwave symposium will offer the following sessions:
- Microwave Processing-Challenges and Opportunities

- Microwave Remediation of Nuclear and Hazardous Waste

- Microwave Sintering

- Process Modeling Simulation and Microwave Interaction Effects

- Microwave Deposition of Diamond Films

- Applications and Microwave-Enhanced Effects

- Novel Microwave Processing

- Microwave Processing of Composites and Joining

- Scale-Up of Microwave Processing

- Dielectric Properties and Measurements

- Microwave Equipment Design

For registration information on the symposium, please contact Jackie Davis at the American Ceramic Society. Phone: (614) 890-4700.

\section{Attention MRS Members-}

The 1993 Spring Meeting Program was mailed recently. If you have not yet received your copy, please notify:

MRS Meetings Department, 9800 McKnight Road, Pittsburgh, PA 15237

Phone: (412) 367-3003 • FAX: (412) 367-4373 